\title{
ANALISIS FAKTOR NISBAH DAN FAKTOR SUKU BUNGA RATA-RATA KREDIT MODAL KERJA BANK KONVENSIONAL YANG MEMPENGARUHI JUMLAH PEMBIAYAAN BAGI HASIL PADA BANK DAN UNIT USAHA SYARIAH DI INDONESIA PERIODE 2005 SAMPAI 2010
}

\author{
Rinto Noviantoro \\ Program Studi Manajemen \\ Fakultas Ekonomi Dehasen Bengkulu \\ rintonoviantoro@yahoo.co.id
}

\begin{abstract}
ABSTRAK
Rinto Noviantoro; Penelitian ini bertujuan untuk mengetahui analisis seberapa besar masing masing faktor, baik dari nisbah maupun dari suku bunga mempengaruhi jumlah pembiayaan bagi hasil di Bank Syariah selama periode tahun 2005 sampai tahun 2010.Metode analisis yang dipakai adalah metode korelasional. Variabel yang diteliti adalah nisbah bagi hasil yang menjadi hak bank dan faktor suku bunga. Hasil penelitian menunjukan bahwa variabel yang digunakan yaitu nisbah dan suku bunga secara bersama-sama dapat mempengaruhi variabel jumlah pembiayaan bagi hasil. Dari hasil olah data tidak ada multikolineraritas, adanya heterokedastilitas, ada auto positif dan data berdistribusi normal
\end{abstract}

\begin{abstract}
Rinto Noviantoro; This study aims to determine how big the analysis of each factor, both of ratio and interest rates affect the amount of financing for the results at the Islamic Bank for the period 2005 to 2010.Metode analysis used a correlation method. The variables studied were the profit sharing ratio is rightfully bank and interest rate factor The results showed that the variables used are ratio and interest together can influence the variable amount of financing for the results. From the results if the data is not there multikolineraritas, the heterokedastilitas, there are positive auto and normal distribution of data Keywords: Ratio, lending and financing for the results.
\end{abstract}

Keywords: Ratio, lending and financing for the results.

\section{PENDAHULUAN}

Sebagai Negara yang mayoritas penduduknya umat Islam, sistem ekonomi syariah harus dilaksankan sebagai sistem ekonomi yang universal, yang mengedepankan transparasi, keadilan dan good governance dalam pengelolaan usaha dan aset-aset Negara. dimana praktek ekonomi yang dijalankan berpihak kepada rakyat dan kebenaran.konsep syariah yang diterapkan dibank, bank sudah membuktikan, bagaimana penyaluran pembiayaan dibank syariah selalu berpihak pada sektor rill, dengan angka finance to deposit ratio yang ralatif tinggi.kehadiran bank syariah terbukti bisa diarahkan untuk mendorong tumbuhnya sektor rill, usaha kecil dan menengah yang selama ini menjadi primadona dan tulang punggung dimasa krisis.

Bank syariah hadir mewakili kebutuhan masyarakat muslim dalam sektor keuangan yang selalu mengacu pada upaya peningkatan kesejahateraan umat muslim secara utuh. Setiap instrumen operasi dan regulasi haruslah merespentasikan konsep maslahat. Keberadaan bank syariah diharapkan dapat memberikan manfaat yang bersifat multidimensional.bukan hanya bersifat keuangan. Haron dan shanmugan (1997) menyimpulkan beberapa tujuan umum keberadaan sistem perbankan dalam pandangan islam, pertama institusi keuangan (perbankan) 
syariah membantu masyarakat muslim untuk dapat bertransaksi sesuai dengan nilai individual dalam sosial yang terkadung dalam islam. Kedua, institusi keuangan syariah dapat mendorong mobilisasi dana masyarakat bagi percepatan pembangunan ekonomi dalam koridor nilai-nilai yang meningkatkan kualitas kehidupan manusia sesuai dengan konsep maslahat.

Bagi Masyarakat muslim, pemilihan jenis kontrak ditentukan oleh minimal dua faktor penentu. Pertama jenis kontrak yang dipilih haruslah dapat memberikan ekspetasi pendapatan yang setinggi-tingginya. Kedua jenis kontrak tersebut haruslah pula sesuai dengan anjuran yang ditentukan dalam syariah.

Meningkatnya presentase pembiayaan melalui pola mudharabah dan musyarakah diharapkan dapat menggairahkan sektor rill. Investasi akan meningkat yang disertai dengan pembukaan lapangan kerja baru.Akibatnya tingkat penganguran akan dikurangi dan pendapatan masyarakat akan bertambah sementara itu ditinjau dari sisi nasabah, nasabah akan memiliki dua pilihan yang pertama apakah akan mendepositokan dananya kepada bank syariah atau bank konvensional. Nasabah akan membandingkan secara cermat antara expected rate of return yang ditawarakan bank syariah dengan tingkat suku bunga yang ditawarkan oleh bank konvensional. Dimana selama ini fakta telah membuktikan. Bahwa ternyata rate of return bank syariah lebih tinggi bila dibandingkan dengan interest rate yang berlaku pada bank konvensional. Sehingga ini akan menjadi faktor pendorong meningkatnya jumlah nasabah.

Bank syariah bertransaksi berdasarkan asset rill dan bukan mengandalkan pada kertas kerja semata.Sementara disisi lain bank konvensional hanya bertransaksi berdasarkan paper work dan dokumen semata, kemudian membebankan bunga dengan presentase tertentu kepada calon investor. Pola pembiayaan mudharabah dan musyarakah adalah pola pembiayaan berbasis pada produksi. Krisis keuangan pun dapat diminimalisirkan kerena laporan keuangan perusahaan relative stabil. Hal ini dikerenakan posisinya sebagai mudharib, dimana perusahaan tidak menanggung kerugian yang ada, apabila kerugian tersebut disebabkan oleh kondisi luar biasa yang tidak diprediksi sebelumnya misalkan akibat bencana alam. Maksudnya keadaan tersebut terjadi secara tidak sengaja dan diluar batas kemampuan. Dengan demikian semua beban kerugian akan ditanggung oleh bank syariah sebagai shahibul maal. Selanjutnya pola mudharabah dan musyarakah dapat menjadi solusi alternative atas masalah kelebihan likuiditas yang saat ini terjadi.

Permasalahan penggunan pembiayaan bagi hasil yang masih rendah ini merupakan masalah yang tidak sederhana, bahkan merupakan masalah yang memiliki multidemensi. Sebuah kenyataan menunjukan, bahwa model pembiayaan yang paling umum digunakan nampaknya adalah murabahah. Dalam murabahah bank membiayai pembelian sebuah barang atau asset dengan membeli item atas nasabahnya dan menambahkan nilai kenaikan sebelum menjual kembali barang itu kepada nasabahnya sesuai dengan perjanjian laba dengan prinsip "tambah biaya "(algaund dan lewis 2003:82 ). Skema murabahah dan juga ijarah sesungguhnya merupakan fixed return model dimana kalau kita mau jujur bahwa yang membedakan secara prinsipil antara bank islam dan bank konvensional diantaranya adalah terletak pada prinsip risk-profit sharingnya. Skema murabahah adalah skema yang cenderung "tidak beresiko".

\section{TINJAUAN LITERATUR Jenis Bank Syariah}

Dalam buku Produk Perbankan Syariah, bank syariah dapat dikelompokkan menjadi 3 jenis dalam undang-undang nomor 21 tahun 2008 tentang perbankan syariah Menurut (Sofyan.S.Harahap \& Wiroso ; 2007, hal 48 ) yaitu :

1. Bank Umum Syariah

Termasuk dalam kelompok Bank Umum Syariah jika seluruh struktur organisasi bank tersebut tunduk pada ketentuan syariah, baik dari kantor pusat sampai dengan kantor layanan baik bawah dari entitas tersebut seluruhnya melaksanakan kegiatan syariah. Contoh: Bank Muamalat 
Indonesia, Bank Syariah Mandiri, Bank Syariah Mega Indonesia, Bank Syariah BRI, Bank Syariah Bukopin.

2. Cabang Syariah Bank Konvensioanl (Unit Usaha Syariah)

Dikategorikan Cabang Syariah Bank Konvensioanl (Unit Usaha Syariah) adalah entitas tersebut menjalankan dua kegiatan usaha bank, yaitu kegiatan usaha konvensional dan kegiatan usaha berdasarkan prinsip usaha syariah. Contoh: BTN Syariah, Bank Jabar Syariah, Bank BNI Syariah.

3. Bank Perkreditan Rakyat Syariah (BPR Syariah)

Kelompok ini adalah Bank Perkreditan Rakyat Syariah yang menjalankan kegiatan usaha sesuai prinsip syariah.

\section{Pembiayaan Bagi Hasil}

Salah satu perbedaan yang mendasar antara bank konvensional dengan bank syariah adalah pembayaran imbalan kepada pemilik dana (investor). Dalam Bank konvensional memberikan imbalan dalam bentuk bunga yang besarnya telah ditetapkan didepan saat akad, sedangkan dalam bank syariah imbalan yang diberikan kepada investor didasarkan hasil usaha yang diterima. Jadi dalam bank syariah sebagian pendapatan merupakan hak pemilik dana (investor).

Perhitungan pembagian hasil usaha antara shahibul maal (pemilik dana) dengan mudharib (pengelola dana), atas hasil usaha yang diperoleh dengan akad mudharabah. Perhitungan selalu dilakukan mudharib, kerena dalam prinsip mudharabah mutlaqah dijelaskan pekerjaan sepenuhnya hak pengelola (mudharib), kerena pekerjaan sepenuhnya hak pengelola maka pengelola yang mengetahui hasil usahanya, sehingga pengelola pula yang melakukan perhitungan pembagian hasil usaha. Oleh kerena itu siapapun yang kedudukannya sebagai pengelola dana, baik bank syariah maupun nasabah debitur, hendaknya dapat meneladani sifat rasul, khususnya amanah, jujur dan transparan. (Wiroso : hal 379)

\section{Nisbah}

Nisbah adalah bagian keuntungan usaha bagi masing-masing pihak yang besarnya ditetapkan berdasarkan kesepakatan. Nisbah bagi hasil merupakan faktor penting dalam menentukan bagi hasil dibank syariah.Sebab aspek nisbah merupakan aspek yang disepakati bersama antara kedua belah pihak yang melakukan transaksi. Untuk menentukan nisbah bagi hasil perlu diperhatikan aspek-aspek : data usaha, kemampuan angsuran, hasil usaha yang dijalankan, nisbah pembiayaan dan distribusi pembagian hasil ( mohammad 2004; hal 86 )

\section{Suku Bunga Kredit Bank Konvensional}

Variabel Lain yang menentukan pertumbuhan ekonomi disektor rill adalah tingkat suku Bunga.Tingkat suku bunga merupakan landasan atau ukuran bagi layak atau tidak layaknya suatu usaha. Tingkat suku bunga juga merupakan indicator penentuan tingkat pengembalian modal atas resiko yang ditanggung oleh pemilik modal dipasar keuangan dan pasar modal. Bunga bank dapat diartikan sebagai balas jasa yang diberikan oleh bank yang berdasarkan prinsip konvensional kepada nasabah yang membeli atau menjual produknya.Bunga bagi bank juga dapat diartikan sebagai harga yang harus dibayar kepada nasabah ( yang memiliki simpanan) dengan harga yang harus dibayar oleh nasabah kepada bank

Secara historis suku bunga hampir setua peradapan manusia.Hal ini diungkapkan oleh kidwell,DS, Peterson, RL dan blackewell, DW ( 1993:133-134) yang menyatakan bahwa ribuan tahun yang lalu orang telah meminjamkan barang kepada orang lain dan kadang-kadang mereka telah meminta semacam kompensasi atas jasa yang diberikan. Kompensasi tersebut disebut sewa, yakni harga dari meminjam harta milik orang lain. 


\section{RIBA}

Riba ada dua macam yaitu

1. Riba al Nasi'ah

Riba al Nasi'ah disebut juga riba duyun, Yaitu riba yang timbul akibat hutang-piutang yang tidak memenuhi kriteria keuntungan muncul bersama resiko dan hasil usaha muncul bersama biaya. Transaksi sejenis ini mengandung pertukaran kewajiban menanggung beban, hanya kerena berjalannya waktu. Nasi'ah adalah penangguhan penyerahaan atau penerimaan jenis barang ribawi yang dipertukarkan dengan jenis barang ribawi lainnya.Memastikan sesuatu yang diluar wewenang manusia adalah bentuk kezaliman

2. Riba al Fadl

Pertukaran antarbarang sejenis dengan kadar atau takaran yang berbeda, sedangkan barang yang dipertukarkan itu termasuk barang ribawi. Riba jenis ini diidentifikasi dan disebut dalam Al Quran dan hadis

\section{KERANGKA PEMIKIRAN}

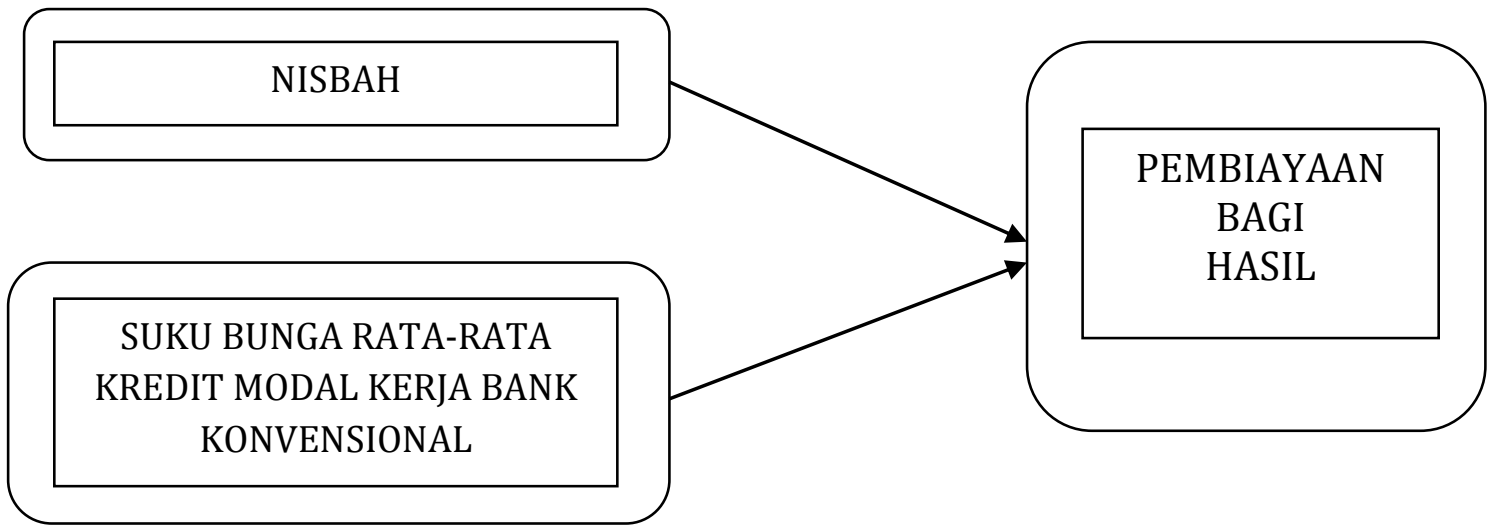

Gambar 1. Kerangka Pemikiran

\section{HASIL PENELITIAN DAN PEMBAHASAN}

Sedangkan kriteria pengambilan keputusannya adalah sebagai berikut: Jika VIF $>10$ atau jika tolerance $<0,1$ maka ada multikolinieritas Jika VIF $<10$ atau jika tolerance $>0,1$ maka tidak ada multikolinieritas

\begin{tabular}{|c|c|c|}
\hline Variabel & VIF & Kesimpulan \\
\hline \multicolumn{3}{|c|}{ Sebelum Penanggulangan masalah autokorelasi } \\
\hline Suku Bunga & 1.063 & Tidak ada multikolinieritas \\
\hline Nisbah & 1.063 & Tidak ada multikolinieritas \\
\hline \multicolumn{3}{|c|}{ Setelah penanggulangan masalah autokorelasi } \\
\hline Suku Bunga2 & 1.027 & Tidak ada multikolinieritas \\
\hline Nisbah2 & 1.027 & Tidak ada multikolinieritas \\
\hline
\end{tabular}

Dari hasil pengujian di atas, semua variabel independen memiliki nilai VIF yang lebih kecil dari 10. Dengan demikian dapat disimpulkan bahwa semua variabel tersebut tidak memiliki masalah multikolinieritas 
Uji heteroskedastisitas dalam penelitian ini dilakukan dengan Uji Arch.

Hipotesis yang digunakan adalah:

Ho : Tidak ada heteroskedastisitas

Ha : Ada heteroskedastisitas

Sedangkan kriteria pengambilan keputusannya adalah:

Jika probabilitas $>$ tingkat kesalahan $(\alpha=0,05)$ maka Ho gagal ditolak (tidak ada heteroskedastisitas).

Jika probabilitas < tingkat kesalahan $(\alpha=0,05)$ maka Ho ditolak (ada heteroskedastisitas).

\begin{tabular}{|c|c|c|c|}
\hline Model & Prob. F & Prob. Chi $^{2}$ & Keputusan \\
\hline Sebelum penanggulan autokorelasi & 0,0000 & 0,000 & Ada heteroskedastisitas \\
\hline Setelah penanggulan autokorelasi & 0,8868 & 0,8858 & Tidak ada heteroskedastisitas \\
\hline
\end{tabular}

Dari hasil uji Arch sebelum penanggulan autokorelasi, didapat nilai Prob. F dan Prob $\mathrm{Chi}^{2}$ lebih kecil dari 0,05. Maka disimpulkan bahwa dalam persamaan regresi ada masalah heteroskedastisitas. Setelah dilakukan penanggulangan autokorelasi didapat nilai Prob F dan Prob $\mathrm{Chi}^{2}$ lebih besar dari 0,05. Dengan demikian, model tidak lagi mengandung masalah autokorelasi.

Pengujian autokorelasi dalam penelitian ini menggunakan uji Durbin-Watson (DW Test). Hipotesis yang digunakan adalah:

Ho : Tidak ada autokorelasi

Ha : Ada autokorelasi

Sedangkan kriteria pengambilan keputusannya adalah sebagai berikut:

a. Apabila nilai DW lebih kecil daripada batas bawah $(0<\mathrm{DW}-\mathrm{stat}<\mathrm{dl})$, koefisien autokorelasi lebih besar daripada nol, berarti ada autokorelasi positif.

b. Apabila nilai DW terletak di antara batas bawah dan batas atas $(\mathrm{dl}<\mathrm{DW}-\mathrm{stat}<\mathrm{du})$ atau terletak di antara 4-du dan 4-dl (4-du<DW-stat<4-dl), maka hasilnya tidak dapat disimpulkan karena berada pada daerah yang tidak meyakinkan (inconclusive).

c. Apabila nilai DW lebih besar dari 4-dl (4-dl<DW-stat<4), maka koefisien autokorelasi lebih kecil daripada nol, berarti ada autokorelasi negatif.

d. Apabila nilai DW terletak antara batas atas dan 4-du $($ du $<$ DW-stat $<4-d u)$, maka koefisien autokorelasi sama dengan nol, berarti tidak ada autokorelasi.

\section{Gambar 2. Kriteria Pengambilan Keputusan Uji Durbin-Watson}

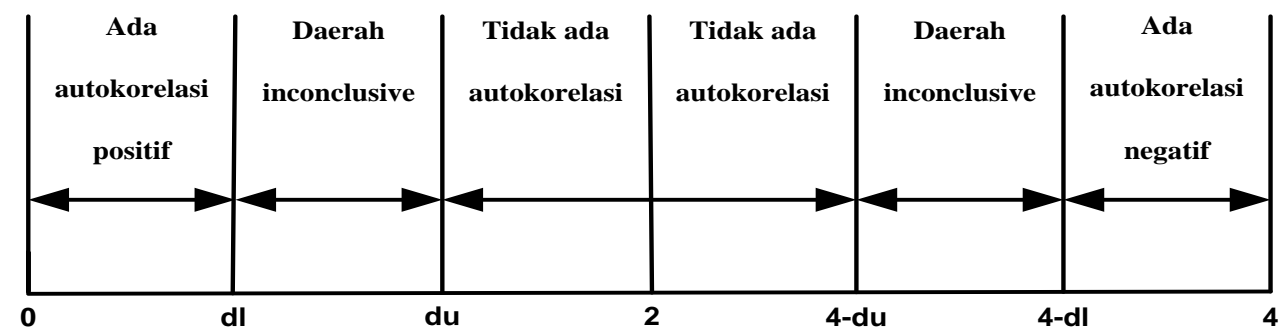

Keterangan:

DW = Durbin-Watson test

$\mathrm{dl} \quad=$ lower bound (batas bawah)

$\mathrm{du} \quad=$ upper bound (batas atas) 


\begin{tabular}{|l|l|l|l|l|l|l|}
\hline Variabel Dependen & $\mathbf{d l}$ & $\mathbf{d u}$ & $\mathbf{4}-\mathbf{d u}$ & $\mathbf{4}-\mathbf{d l}$ & $\mathbf{D W}$ & Keputusan \\
\hline $\begin{array}{l}\text { Ln_Pembiayaan Bagi } \\
\text { Hasil }\end{array}$ & 1,706 & 1,760 & 2,294 & 2,240 & 0,225 & Ada autokorelasi positif \\
\hline $\begin{array}{l}\text { Ln_Pembiayaan Bagi } \\
\text { Hasil2 }\end{array}$ & 1,706 & 1,760 & 2,294 & 2,240 & 2,074 & Tidak ada autokorelasi \\
\hline
\end{tabular}

Dengan jumlah observasi 143, dan jumlah variabel bebas 2 , didapat nilai dl 1,706 dan du 1,760. Dari hasil pengolahan SPSS didapat nilai DW 0,225 yang berada pada daerah ada autokorelasi positif. Dengan demikian, terdapat masalah autokorelasi dalam model persamaan.

Untuk mengatasi masalah autokorelasi dilakukan regresi generalize difference equation, yaitu regresi $\mathrm{X}$ terhadap $\mathrm{Y}$ tidak pada bentuk aslinya, tetapi pada selisih yang diperoleh dengan mengurangkan suatu proposi $(\rho)$ nilai variabel sebelumnya dari nilai variabel yang bersangkutan. Setelah dilakukan perbaikan pada model, didapat nilai DW 2,074 yang berada didaerah bebas autokorelasi.

\section{Gambar 3. Hasil uji normalitas sebelum penanggulangan autokorelasi} Normal P-P Plot of Regression Standardized Residual

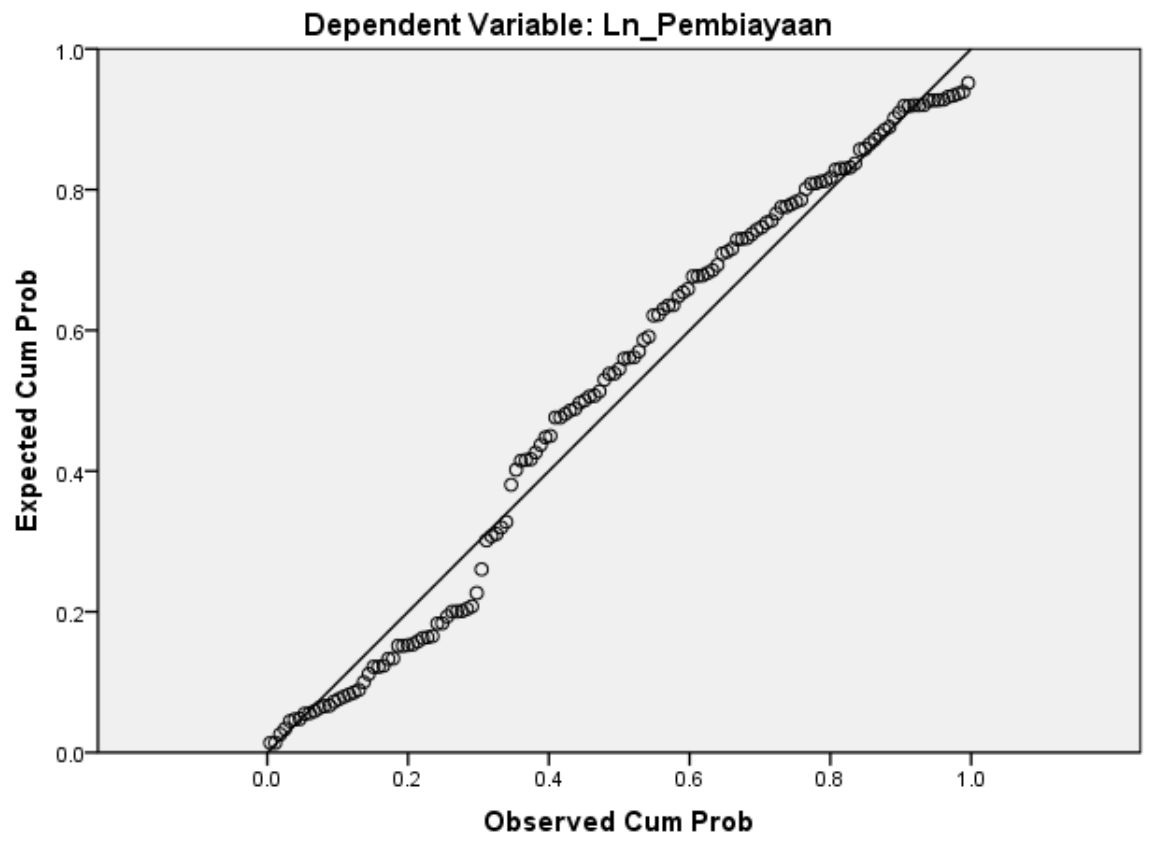

Dari hasil pengujian didapat bahwa data menyebar disekitar garis diagonal dan mengikuti arah garis diagonal grafik, maka hal ini menunjukan pola terdistribusi normal. Dengan demikian model persamaan regresi yang digunakan memenuhi asumsi normalitas. 


\section{Gambar 4. Hasil uji autokorelasi setelah penanggulangan}

Normal P-P Plot of Regression Standardized Residual

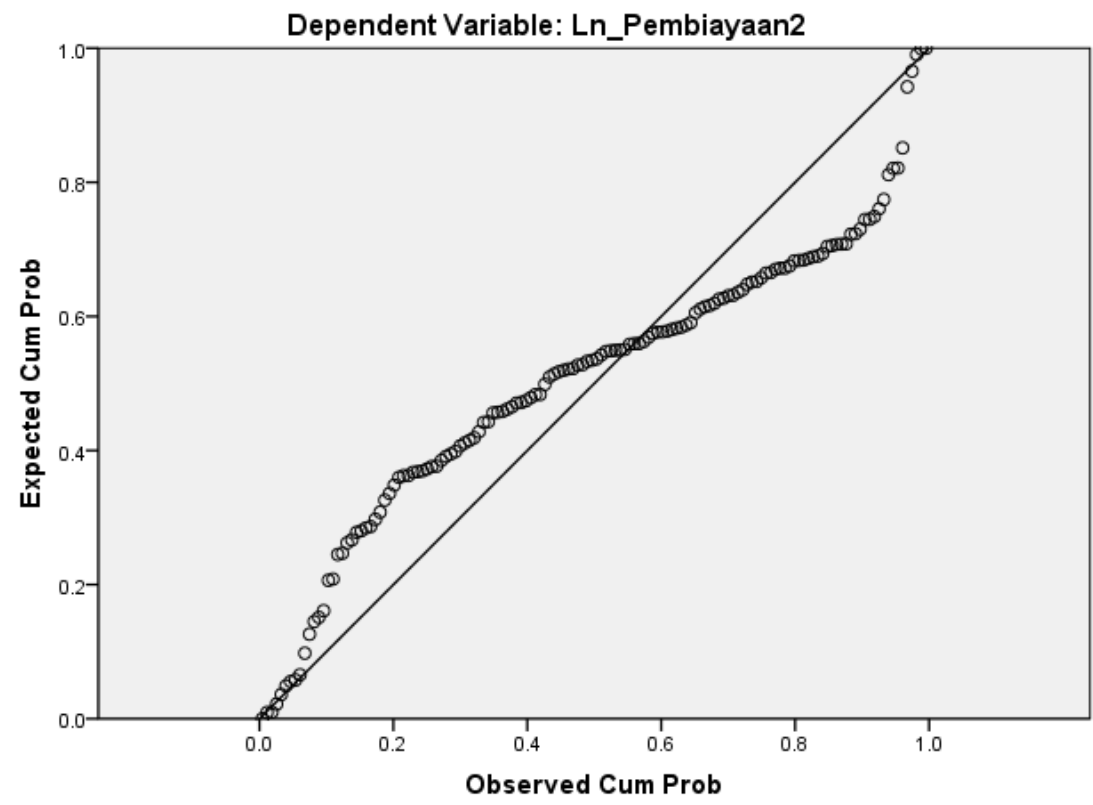

ANALISIS REGRESI

\begin{tabular}{|l|r|c|}
\hline \multicolumn{3}{|c|}{ Variabel Dependent: } \\
Ln_Pembiayaan Bagi Hasil2 \\
\hline \multicolumn{1}{|c|}{ Variabel Independent } & \multicolumn{1}{|c|}{ Koefisien } & \multicolumn{1}{c|}{ Sig } \\
\hline Konstanta & 3,102 & 0,000 \\
\hline Suku Bunga2 & $-0,386$ & 0,036 \\
\hline Nisbah2 & 0,081 & 0,000 \\
\hline R-squared & 0,101 \\
\hline Adjusted R-squared & 0,088 \\
\hline F-stat & 7,766 \\
F-prob & 0,001 \\
\hline
\end{tabular}

\section{Goodness of Fit Models}

Adj R-squared $=\mathbf{0 . 0 8 8}=\mathbf{8 , 8 0} \%$

Artinya, kemampuan variabel independent dalam menjelaskan perilaku variabel dependent sebesar 8,80 persen sedangkan sisanya sebesar 91,20 persen dijelaskan oleh variabel lain yang tidak dimasukkan kedalam model.

\section{Uji F}

Pengambilan Keputusan

Jika sig dari Fstat $>0.05$, maka Ho diterima

Sig dari Fstat $<0.05$, maka Ho ditolak

Kesimpulan

Hasil pengolahan menunjukkan bahwa dengan nilai Fstat sebesar 7,766 dan sig dari Fstat sebesar $0,001<0.05$ maka Ho diterima atau secara bersama-sama variabel independent signifikan 
mempengaruhi variabel dependent. Dengan demikian, Suku Bunga dan Nisbah secara serentak memiliki pengaruh yang signifikan terhadap Pembiayaan Bagi Hasil

\section{UJI T}

a. Suku Bunga dan Pembiayaan Bagi Hasil

Hipotesa

$\mathrm{H}_{0}: ß_{1} \neq 0$ artinya tidak ada pengaruh Suku Bunga terhadap Pembiayaan Bagi Hasil

$\mathrm{H}_{1}:{ }_{1}=0$ artinya ada pengaruh Suku Bunga terhadap Pembiayaan Bagi Hasil

Suku Bunga berpengaruh negatif terhadap Pembiayaan Bagi Hasil seperti ditunjukkan dengan nilai koefiisen regresi sebesar -0,386. Hasil pengujian t-statistik menunjukkan nilai probabilita dari t sebesar 0,036 0,05 sehingga hipotesa null ditolak atau ada pengaruh negatif yang signifikan Suku Bunga terhadap Pembiayaan Bagi Hasil. Semakin tinggi tingkat suku bunga, maka pembiayaan bagi hasil akan semakin menurun.

b. Nisbah dan Pembiayaan Bagi Hasil

Hipotesa

$\mathrm{H}_{0}: \aleph_{2} \neq 0$ artinya tidak ada pengaruh Nisbah terhadap Pembiayaan Bagi Hasil

$\mathrm{H}_{2}: \AA_{2}=0$ artinya ada pengaruh Nisbah terhadap Pembiayaan Bagi Hasil

Nisbah berpengaruh positif terhadap Pembiayaan Bagi Hasil seperti ditunjukkan dengan nilai koefiisen regresi sebesar 0,081. Hasil pengujian t-statistik menunjukkan nilai probabilita dari t sebesar 0,000 $<0,05$ sehingga hipotesa null ditolak ada pengaruh positif yang signifikan Nisbah terhadap Pembiayaan Bagi Hasil. Semakin tinggi nisbah, maka Pembiayaan Bagi Hasil juga akan semakin meningkat.

\section{Uji Beda 2 Rata-rata Uji Normalitas}

Uji normalitas bertujuan untuk menguji apakah data variabel mempunyai distribusi normal atau tidak. Uji normalitas dalam penelitian ini dilakukan dengan Uji Kolmogorov-Smirnov. Hipotesis yang digunakan dalam uji Kolmogorov-Smirnov adalah:

Ho : Data berdistribusi normal

Ha : Data tidak berdistribusi normal

Sedangkan kriteria pengmbilan keputusannya adalah:

1) Jika probabilitas $>0,05$ maka Ho diterima dna Ha ditolak (data berdistribusi normal).

2) Jika probabilitas < 0,05 maka Ho ditolak dan Ha diterima (data tidak berdistribusi normal).

Apabila data tidak berdistribusi normal, maka sebaiknya tidak dilakukan pengujian dengan menggunakan statistik parametrik, yaitu Independent Sample Test tetapi menggunakan statistik non parametrik yaitu Uji Mann-Whitney

\begin{tabular}{|l|c|c|}
\hline \multicolumn{1}{|c|}{ Variabel } & Signifikansi & \multicolumn{1}{c|}{ Kesimpulan } \\
\hline Nisbah & 0,000 & Data tidak terdistribusi normal \\
\hline Ln_Pembiayaan & 0,001 & Data tidak terdistribusi normal \\
\hline
\end{tabular}

Dari hasil pengujian SPSS didapat nilai signifikansi untuk Nisbah dan Ln_Pembiayaan lebih kecil dari 0,05 sehingga Ho ditolak atau data tidak terdistribusi secara normal. Oleh karena itu, untuk menguji perbedaan Nisbah dan Ln_Pembiayaan antara Unit Usaha Syariah dan Bank Umum Syariah alat analisis yang digunakan adalah Uji Mann-Whitney 


\section{Mann Whitney Test}

Uji dua sampel bebas pada statistik non parametrik mempunyai tujuan yang sama dengan uji t pada statistik parametrik, yaitu ingin mengetahui apakah dua buah sampel bebas berasal dari populasi yang sama.

\begin{tabular}{|l|c|}
\hline Variabel & Signifikansi \\
\hline Nisbah & 0,064 \\
\hline Ln_Pembiayaan & 0,085 \\
\hline
\end{tabular}

Hipotesis $4 \mathrm{a}$

Ho $: \mu_{\text {nisbah1 }}=\mu_{\text {nisbah2 }}$ Tidak terdapat perbedaan nisbah pada Unit Usaha Syariah dengan Bank Umum Syariah

H4a : $\mu_{\text {nisbah1 }} \neq \mu_{\text {nisbah2 }}$ Terdapat perbedaan nisbah pada Unit Usaha Syariah dengan Bank Umum Syariah

Dari hasil pengujian SPSS didapat nilai signifikansi untuk nisbah adalah sebesar 0,064 sehingga Ho gagal ditolak. Dengan demikian, tidak ditemukan adanya perbedaan Nisbah yang signifikan antara Unit Usaha Syariah dengan Bank Umum Syariah.

Hipotesis $4 \mathrm{~b}$

Ho $\quad: \mu_{\text {pembiayaan1 }}=\mu_{\text {pembiayaan2 }}$ Tidak terdapat perbedaan pembiayaan pada Unit Usaha Syariah dengan Bank Umum Syariah

H4b $\quad: \mu_{\text {pembiayaan1 }} \neq \mu_{\text {pembiayaan2 }}$ Terdapat perbedaan pembiayaan pada Unit Usaha Syariah dengan Bank Umum Syariah

Dari hasil pengujian SPSS didapat nilai signifikansi untuk nisbah adalah sebesar 0,085 sehingga Ho gagal ditolak. Dengan demikian, tidak ditemukan adanya perbedaan Pembiayaan yang signifikan antara Unit Usaha Syariah dengan Bank Umum Syariah.

\section{Kesimpulan}

Berdasarkan analisa dan pembahasan hasil yang telah dikemukakan sebelumnya maka dapat ditarik kesimpulan bahwa Pengujian terhadap masalah penelitian yang dilakukan dengan menggunakan uji regresi linier berganda untuk menjelaskan pengaruh nisbah dan suku bunga terhadap variabel dependen pembiayaan bagi hasil diperoleh hasil bahwa;

1. Hasil dari penelitian nisbah berpengaruh positif dan signifikan terhadap jumlah pembiayaan bagi hasil Penjelasan tersebut mendukung pernyataan bahwa semakin tinggi nilai nisbah bagi hasil dengan Pembiayaan Bagi Hasil akan semakin meningkat kerena kebijakan bank syariah yang menyisihkan sebagian sebagian keuntungannya untuk ekspansi bisnis dalam bentuk pembiayaan bagi hasil di bank syariah

2. Hasil dari penelitian suku bunga berpengaruh negative yang signifikan terhadap pembiayaan bagi hasil dimana bahwa hal ini disebabkan dalam pembiayaan bank syariah masih mengacu pada suku bunga bank konvensional untuk meningkatkan kinerja bank syariah

3. Hasil Penelitian Nisbah, suku bunga rata-rata kredit modal kerja berpengaruh terhadap jumlah pembiayaan bagi hasil Hal ini menyiratkan bahwa kedua variabel ini nisbah dan tingkat suku bunga mengikuti mempengaruhi peningkatan dan penurunan permintaan pembiayaan bagi hasil pada bank syariah dan unit usaha syariah.dimana dalam pembiayaan bagi hasil sangat berpengaruh terhadap nisbah maupun suku bunga didalam kinerja bank syariah 
4. Dengan demikian, tidak ditemukan adanya perbedaan Nisbah dan pembiayaan yang signifikan antara Unit Usaha Syariah dengan Bank Umum Syariah karena bank umum syariah dan unit usaha syariah menerapkan bagian perhitungan nisbah dan pembiayaan bagi hasil.

\section{Implikasi Manajerial}

Berdasarkan dari kesimpulan diatas, maka hasil penelitian ini selayaknya dapat digunakan oleh manajemen perbankan syariah agar memperhatikan penentuan nisbah dan tingkat suku bunga sangat mempengaruhi minat nasabah untuk ikut dalam transaksi keuangan yang pada akhirnya akan memberikan dampak bagi pembiayaan bagi hasil pada perbankan syariah baik secara parsial maupun simultan yang diteliti dalam penelitian ini sehingga dapat menjadi salah satu acuan informasi tambahan untuk meningkatkan kinerja keuangan perbankan syariah kearah yang efektif dan efisien .

\section{Saran dan keterbatasan Untuk Penelitian Selanjutnya}

Penelitian ini menggunakan sampel dari tahun 2005 - 2010. Untuk penelitian selanjutnya disarankan untuk menambah jumlah obyek, sampel penelitian dan jumlah data serta menggunakan model yang tepat agar hasil yang diperoleh lebih tepat/akurat. Selain itu juga menambah variabel lain yang memberikan dampak signifikan terhadap permintaan pembiayaan bagi hasil

Dalam penelitian ini, penulis mencatat beberapa kekurangan dan keterbatasan yang sekaligus merupakan kelemahan dari thesis ini, antara lain:

1. Penelitian ini mengunakan data time series triwulan dari laporan keuangan bank umum syariah dan unit usaha syariah yang dipublikasikan. Data time series yang digunakan masih terbatas, sementara untuk analisis data series semakin panjang data , maka akan semakin baik.

2. Dengan adanya variabel suku bunga dan nisbah yang mempengaruhi jumlah pembiayaan bagi hasil ,maka penulis membutuhkan banyak variable agar dapat menguatkan terhadap argumentasi yang telah ada.

Berdasarkan kelemahan-kelemahan diatas, maka untuk selanjutnya penulis menyarankan perlunya penelitian lanjutan mengenai pembiayaan bagi hasil di bank dan unit usaha syariah dengan menggunakan model dan variable yang lebih banyak.

\section{DAFTAR PUSTAKA}

Antonio, Muhammad Syafi'i. 2001.Bank syariah dari teori ke praktek, Jakarta : Gema Insani persTazkia cendikia.

Chapra, Umar,2001.The future of economics an Islamic perspektif.Jakarta.SEBi

Chapra, Umar, 2000 , Sistem Moneter Islam. Jakarta .Gema Insani Pers.

Diwany, Tarek El.2005.The problem with interest.Jakarta.Akbar media eka sarana.

Iljas, Achjar, 2004, Perbankan syariah: tinjauan terhadap pembiayaan bagi hasil, Jurnal Equlibrium Ekonomi dan Kemasyarakatan Volume 2 No 2 , Jakarta, STIE Ahmad Dhalan.

Karim, Adiwarman, 2003, Bank Islam-Analisis fiqih dan keuangan, Jakarta : IIIT Indonesia

Karim, Adiwarman.2008.Ekonomi Makro Islam.Jakarta.PT Rajagrafindo Persada. 
Kasmir,2002, Bank dan Lembaga Keuangan Lainnya.Jakarta, PT RajaGrafindo.

Muhammad, 2004, Teknik perhitungan bagi hasil dan profit margin pada bank syariah, Yogyakarta, UII Press

Harahap. S.Sofyan. 2007.Akuntansi Perbankan Syariah Edisi Revisi. Jakarta.LPFE Usakti.

Harahap, Syabirin. 1984. Bunga Uang dan riba dalam hokum Islam.Jakarta.Pustaka Al Husna.

Nachrowi, Djalal dan Hardius Usman. 2002. Penggunaan teknik Ekonometri, Jakarta : PT RajaGrafindo Persada.

Nopirin, 1993, Ekonomi Moneter, Buku I, Yogyakarta, BPFE Yogyakarta.

Rivai, Veithzal,Veitzhal, Andria permata, Rizqullah.2010. Islamic financial Management 1. Jakarta.Ghalia Indonesia

Rivai, Veithzal. 2007. Bank And Financial Institution Conventional and Sharia System. Jakarta . PT Raja Grafindo Persada.

Pracoyo, Antyo. Pengaruh pendapatan bagi hasil dan suku bunga rata-rata kredit modal kerja bank konvensional terhadap pembiayaan bagi hasil pada bank syariah XYZ ( periode maret 2003 - maret 2008 ). Media Ekonomi, Vol 14 No 1.April 2008.

Puspopranoto, Sawaldjo.2004.Keuangan perbankan dan pasar keuangan.Jakarta. LP3ES

Pusat Pengkajian dan Pengembangan Ekonomi Islam UII dengan BI. 2008 . Ekonomi Islam.Yogyakarta.PT Raja Grafindo Persada

Wiroso. 2009. Produk Perbankan Syariah . Jakarta . LPFE IBFI Trisakti. 